\title{
[Under Review]
}

\section{Grassroots creative hubs: urban regeneration, recovered industrial factories and cultural production in Buenos Aires and Rio de Janeiro \\ Dr Cecilia Dinardi}

Goldsmiths, University of London

\section{Introduction}

This chapter examines the nature, functioning and politics of grassroots creative hubs as contained in refurbished industrial factories. The renewal and transformation of factories into arts and cultural venues has been a key feature of post-industrial urbanism in the last three decades. Examples abound across the world, from railway and power stations to post office buildings and chocolate factories, these recovered infrastructures have been re-signified as cultural facilities - performing or multi-arts centres, galleries, cultural centres, creative economy laboratories, incubators and museums. These initiatives, be that they are led by local governments or community groups, are part of broader urban strategies for revitalising historical centres, revalorising cultural heritage and creating work opportunities as well as resources for tourism and business investment. But can a factory building be considered a creative hub? Does the materiality of these urban artefacts provide a solution to the oftentransient nature of ephemeral cultural urbanism?

Refurbishing old industrial factories and warehouses for cultural use and creative production has been the subject of much investigation since the 1980s-1990s, mainly through the study of culture-led urban regeneration and gentrification (Zukin, 1989; Montgomery, 1995; Evans and Shaw, 2004; Mommaas, 2004; Pratt, 2009), and more recently, creative industry clusters and districts (Evans, 2009; Zukin and Braslow, 2011; O'Connor and Gu, 2012). These studies have pointed out the problems that arise from 
the organisation, management and long-term sustainability of converted industrial sites, as well as from the policy uses and abuses that often pave the way to real-estate development and social displacement.

Drawing on insights from urban sociology and critical geography, the chapter conducts a case-study analysis of two cultural and creative economy factories in Latin America: Fábrica Bhering in Rio de Janeiro, Brazil, and IMPA, la Fábrica Cultural in Buenos Aires, Argentina. The chapter is comprised of three sections: the first discusses whether recovered industrial factories can be thought of as creative hubs in relation to ephemeral cultural urbanism; the second examines the two case-studies in the context of Brazil and Argentina; and the third offers concluding remarks. Overall the chapter contributes a Latin American perspective on culture-led urban regeneration to the study of creative hubs. Particularly, grassroots creative initiatives of urban renewal are presented as an alternative to the exclusionary gentrification processes to which creative hubs and other territorial forms of creativity are often related to, in times largely shaped by neoliberal operations driven by real-estate interests and alliances between political and economic urban elites.

\section{Converted factories as creative hubs?}

Creative hubs can be approached and questioned on a number of levels: whether they have been planned or developed spontaneously, what their financial and management models are, how creative labour is organised (including issues of class, gender and ethnicity), with regards to past and present uses of space and their urban impact, and in relation to wider socio-economic and political contexts. But what makes a site of cultural production or an arts centre a 'creative hub'? Are creative hubs to be defined by the activities taking place inside them, the subjects that make them, or the outputs produced? 
Hubs are centres of production and they are central to the making or functioning of things or activities. In its original meaning, the term hub was first used as an English dialect in the 16th century to refer to the 'hob', the antique version of modern cookers, a heating device which, by the 17th century, had become the 'central part of a wheel' (Cresswell, 2010: 215), an essential element of a machine. If creative hubs can be related to the idea of the city as a machine, what urban political economists might term a 'growth machine' (Molotoch, 1976), we can expect to find both urban development and investment in and through the creative hubs/creative economy, as well as tensions with local residents, who might be left out from such urban processes and might oppose new uses of spaces or buildings. We will see that both converted factories, Bhering and IMPA, are constitutive parts of their cities' creative economies, providing labour force, goods, services and infrastructures, and function as 'hubs' - in the form of networks and events - within particular local cultural circuits. And they are also contested and contestatory spaces. As a Bhering artist protested, the factory wasn't a 'cultural centre' in his view, but rather, a commercial space becoming increasingly market-driven and attracting a larger number of mainstream events.

Another important question relates to the changing nature and the temporality of the creative hub. Ontologically these spaces are often 'in the process of becoming' and their material future tends to be uncertain in view of the usual lack of funding or policy support. Becoming a 'creative hub' can seem the result of a branding operation or an equally marketable - policy strategy to orient or attract funding and investment. When does a venue become a hub? Does time matter in defining creative hubs? The rise of ephemeral urbanism, with its pop-up and recycled uses of buildings and spaces, gives us a sense of the larger scale on which these urban processes operate, reminding us that nothing is permanent and constant change is the norm. Non-permanence, openness, adaptation and flexibility define the ephemeral landscapes of the new urban condition (Mehrotra, Vera and Mayoral, 2016) and seem to be features of creative hubs too. Although the materiality of large factories such as Bhering or IMPA roots hubs in 
fixed space and one might say, anchors them in a temporal dimension where history is not to be forgotten thanks to the presence of their industrial architecture, the factory's functions, aesthetics, uses and users inevitably change with time, and in doing so, they create an opportunity to engage with its past in creative ways, or surrender it to oblivion.

For instance, in 'How to build a creative hub' Strauss (2010) identifies a number of factors that allegedly can lead to the success of the hubs: the right fit, defined as being able to select who participates; good facilities provision - internet, meeting spaces, kitchen, cafes and restaurants; the ability to build partnerships across members; communal working with social spaces; and affordable rents. Strikingly, this account makes no reference to the history of the area where the hubs are located, the previous and current uses of the building in question, the existing population and activities in the surrounding area, and the relation between the hubs and the wider policy context of support (or lack thereof) for the creative economy.

In short, creative hubs show how a particular type of labour gets organised in postindustrial societies and reveal the spatiality that the new economy creates. If the creative city was to be interpreted as the new style of urbanisation generated by the post-fordist economic order (Scott, 2006), what do cultural spaces such as Bhering or IMPA reveal about the state of the cultural and the creative economy in Latin American cities and beyond? Apart from giving us clues about the governance of the cultural sector and the complex relationship between state and civil society, they reflect the decay and abandonment produced by the failure of (national policies in support of) manufacturing economies and global economy shifts towards post-industrialisation. Furthermore, they allow us to observe how at the grassroots level that void is filled by spontaneous, bottom-up experiences that resort to creativity to self-generate jobs and workspaces. Some cases of planned creative hubs, in contrast, might reveal a type of fast-food policy where quick, easy and already processed recipes are sought to 
revitalise neighbourhoods by resorting to culture as a panacea, that is, a universal magic cure to all urban illnesses (Dinardi, 2015).

In the Latin American context, the institutional field of the creative economy is developing rapidly. Creative hubs have been understood as 'polos creativos' (in Spanish) or 'distritos criativos' (in Portuguese) and in the last decade they have been at the centre of public policy initiatives aimed at local economic development, through an agglomeration of creative activities, tax incentives and targeted training, particularly in deprived city areas. At the same time, grassroots creative hubs have existed for long, without using the 'creative hub' label, as self-managed (autogestionados) or community-run cultural centres, with collaborative learning, informal networks and shared spaces for cultural production. Despite the central importance of the creative economy for the region, its contribution to employment and national economies remains, to a large extent, invisible to official measurements and the general public (Buitrago and Duque, 2013).

In the case of Brazil, creative hubs can be interpreted within the so-called entrepreneurialisation of society, where policy discourses and public investment at various governmental levels have praised since 2000s technology-based start-up urbanism as a catalyst for local economic development and urban regeneration through neoliberal and neo-developmentalist approaches (Rossi and Di Bella, 2017). Rio de Janeiro, in particular, has pioneered the production of data about the creative sector, publishing creative industry mapping documents back in 2008 (by FIRJAN, the Federation of Rio de Janeiro State Industries), and launching new specialised governmental bodies, such as Rio Criativo Incubation Agency. The internationalization of Rio with the hosting of mega-events (World Cup in 2014 and the Olympic Games in 2016) created a narrative of a city of events, which in turn rendered it the main beneficiary of Brazil's public initiative for creative start-ups, supported by a range of 
actors, institutions and interests, including banks, businesses, universities, media and NGOs (Rossi and Di Bella, 2017).

Brazil's current meltdown, seen in the controversial removal of democratically elected President Dilma Rouseff by Congress members and the recent political corruption scandals and detentions of public servants, create a context of deep uncertainty, social unrest and anxiety over the future, particularly in light of Rio de Janeiro's high levels of unemployment, social deprivation, increasing levels of violence, public funding cuts, and the military control of the city, which inescapably disrupts and complicates the prospects of any cultural initiative or policy.

In the case of Argentina, a similar creative industry institutional scenario has been developing, with the early creation of the Metropolitan Design Centre (CMD) in Buenos Aires back in 2001, the subsequent Creative Industries General Direction, official observatories and laboratories, the Creative Economy National Secretary, and the launch of the specialised market for Argentina's creative industries (MICA), running since 2011, which has recently acquired a regional dimension with MICSUR (the creative industries market of MERCOSUR's countries). The creative districts policy at the city government level, now under the orbit of the Ministry of Modernisation, Innovation and Technology, epitomises the current (Mauricio Macri's) administration's approach towards the creative economy: the promotion and organisation of creative activities into geographical clusters, through the creation of five creative districts (audio-visual, technological, arts, design and sports) in the city's Northern and Southern neighbourhoods, as key marketing tools for urban and economic development, in a national context shaped by the shrinking of the state and public spending as well as a tarifazo policy (increase in basic utility fares). 


\section{Case studies from two Latin American cities}

\section{Fábrica Bhering, Rio de Janeiro, Brazil}

Originally a chocolate and sweets factory, Fábrica Bhering has become one of the largest centres for arts production and creative economy in Rio de Janeiro, Brazil. Located in the neighbourhood of Santo Cristo in the city's port region, the factory provides in its 20,000 sq. metres workspace to over 70 artists and 20 small creative enterprises across a range of fields - from sculpture, visual arts and photography, to video art, design, restoration and multimedia. There is also gallery space, a book publisher, a restaurant and a café, and factory space is available for cinema and television rental and for private events.

Built in 1934, Bhering used to employ over a thousand workers in the making of sweets until 2003, when it closed down due to major economic problems. The closure of the factory reflects a wider process of industrial decline that affected the city during the 1990s and profoundly transformed its central and port areas, which witnessed both deterioration and abandonment as well as redevelopment and renewal. As factory owner Rui Barreto stated, 'The history of Bhering is the very history of the development of the occupation of Rio de Janeiro'. The revitalisation of the area involved the refurbishment of old buildings and the construction of new structures, a retail boost, and the development of cultural activities, venues and institutions that de-centralised the concentration of cultural infrastructures in the Southern neighbourhoods (Fessler Vaz and Silveira, 1994:96).

In that context, the factory owners (the Barreto family) found in the arts market a solution to the problem of economic decline. They began to let factory spaces to artists who, from 2010, started to move into the building spontaneously through word-of- 
mouth. The Barreto family had a large tax debt with the federal government, which led to a judicial auction in 2011 and an offer was made by a real estate company which finally bought the building to the federal government. The factory owners contested the value at which the building was sold as well as the judicial auction, since they claimed they were paying back their debt. The artists-tenants, unaware of the auction, received eviction notices to leave the factory within thirty days, which they resisted by organising an online campaign to save what had become an 'arts factory'. The judge who authorised the judicial auction has been investigated in view of various irregularities in the process. 

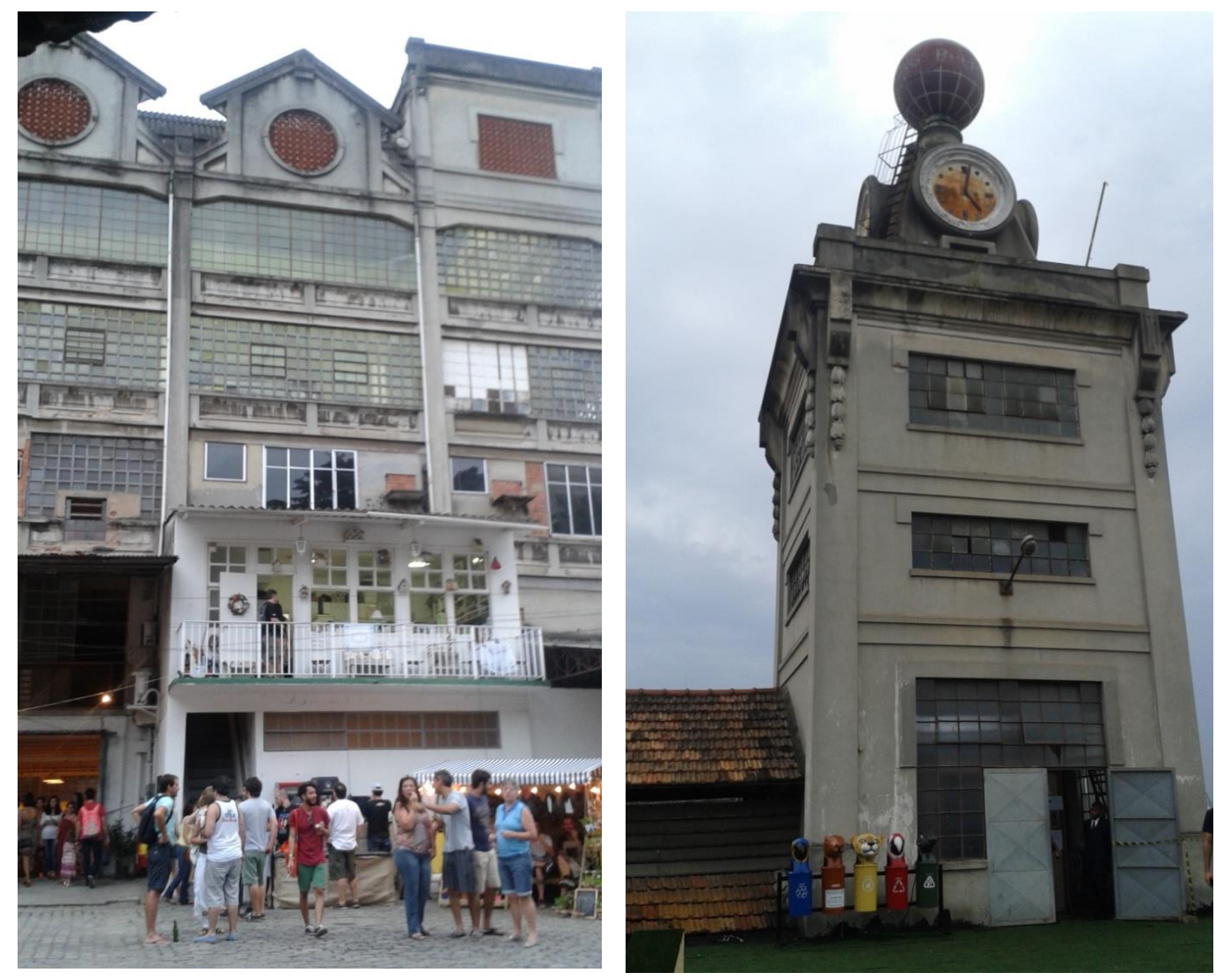

Figure 1. Bhering Factory. Source: Dinardi, 2015.

Surprisingly, the municipal government announced the potential expropriation of the building in 2012 by issuing an official decree which declared it part of the city's heritage in view of its architectural value and importance for the urban landscape. Rio de Janeiro former Mayor (2009-2017), Eduardo Paes, expressed his support in his twitter account to the fifty artists who were then occupying Bhering:

'The eviction of various art spaces in the old Bhering Factory in the port area makes no sense, even considering the small amount for which the building was taken to auction. We will act to stop this nonsense. It is 
precisely that function that we want the area to perform' (Paes, 30/07/2012) [original in Portuguese, author's translation]

It is important to note that Santo Cristo, adjacent to the Gamboa, Saúde and Caju districts in the central area of Rio de Janeiro, is part of what is termed the city's port region, which has undergone dramatic transformation since 2009 to host the 2016 Olympic Games. The municipal government's large urban operation, Porto Maravilha (Wonderful Port), sought to revitalise Rio's decayed port region and boost its economic development through high-impact interventions in public space, transport, urban infrastructure, culture and heritage, and property development (mostly for commercial, residential and institutional use). In terms of cultural development, initiatives included the (re)development of cultural infrastructure (Museu de Arte do Rio de Janeiro, and Museu do Amanhã by star-architect Santiago Calatrava), restoration of heritage buildings, and a series of events, festivals and entrepreneurial activities.

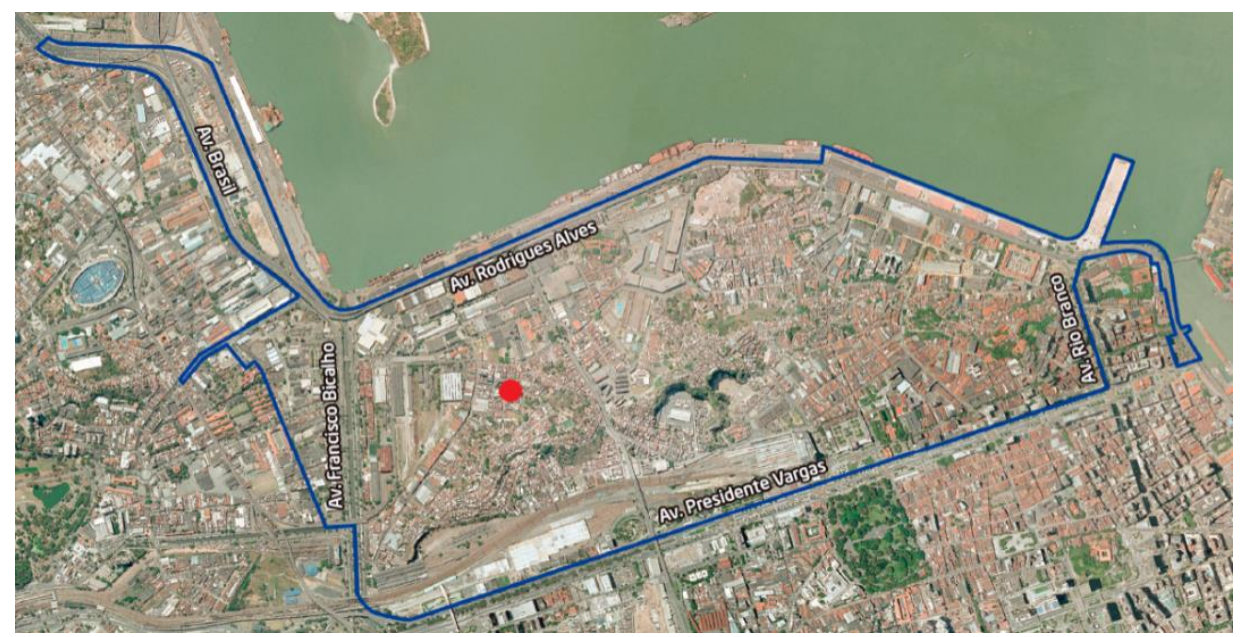

Figure 2: Rio de Janeiro's 5 million square-metre region of the Porto Maravilha programme. The red spot shows the location of Fabrica Bhering [author's composition]. Source: Porto Maravilha's website.

However, Porto Maravilha has been planned as an ideal city of spectacles created for urban branding and mediatised cultural consumption (Jaguaribe, 2011). The urban renovation project, following a neoliberal entrepreneurial logic, has used public funds mainly to benefit private investors and landowners (Diniz, 2014). It has also shown a 
lack of attention and consideration towards local residents, who have attempted to resist forced evictions and new uses of space through community mobilization in view of the absence of adequate official mechanisms to mitigate a gentrification process in the port area (Carlos, 2010).

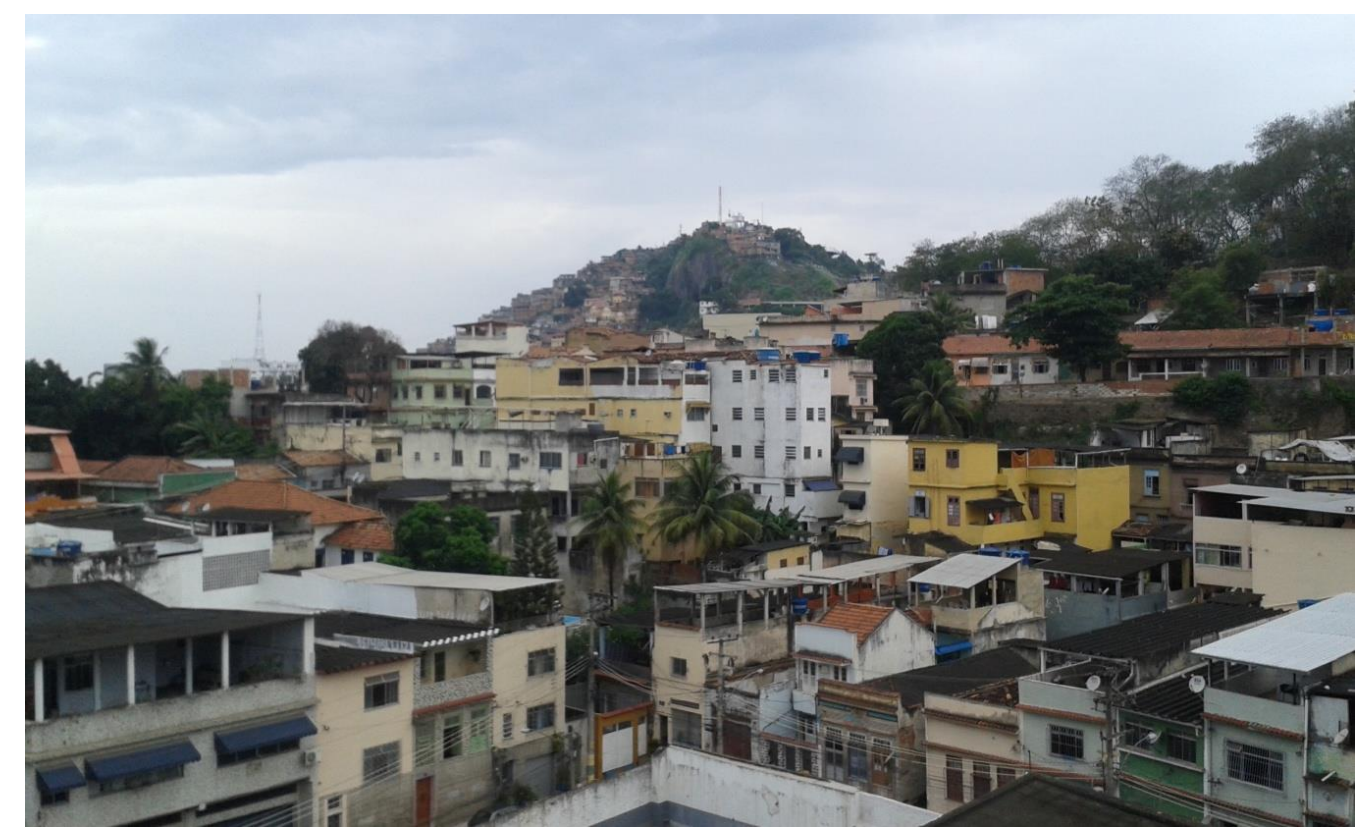

Figure 3: View of the surroundings from Factory Bhering's terrace. Source: Dinardi, 2015.

Far from being an invisible underground initiative, Bhering is today one of the city's main creative hubs and appears listed in Mapa de Cultura, a state government's online platform as well in Time Out magazine. It is also one of the venues of the popular Rio Design Week and Art Rio festival. It is interesting to consider the relationship between Bhering artists and the local authorities. Advised by the later, the artists created a civil association and successfully applied for government funding (Porto Maravilha Cultural awards) to develop a one-off event aimed at getting closer to local residents by offering free workshops, activities and training. In this way, the factory functions indirectly as an intermediary between the local residents and the newly transformed port area, raising the question of artists' - and creative hubs' - unintentional complicity in gentrification processes. 


\section{IMPA Ciudad Cultural, Buenos Aires, Argentina}

IMPA cultural factory was born out of Argentina's 2001 profound political, economic, social and institutional crises. The implementation of a series of neo-liberal policies, particularly during the 1990s, created a context of economic instability with substantial foreign debt, the privatisation of key public services, spending cuts, long recession and increasing social exclusion with high unemployment rates and incessant strikes. In such a context, the devaluation of the national currency in a highly dollarized economy and the governmental restriction to access and withdraw personal savings in banks sparked social protests across the country, including riots and supermarket looting. Potbanging protests took to the streets demanding to 'throw all politicians out!' and ended in the resignation of former President De La Rua.

In the aftermath of these crises, the country witnessed the return of barter clubs and alternative currencies, the emergence of new political actors such as picket organisations and neighbourhood-based public assemblies, and an explosion of the fábricas recuperadas (recovered factories) phenomenon, which included 170 factories between 2001-2003 (Micheletto, 2003) and 480 nowadays (Rivas Molina, 2016). IMPA was the first factory to be taken over and run by workers. Founded in 1910, it produced aluminium and plastic packaging in three industrial plants in Buenos Aires, being the one in Almagro neighbourhood the only that persists to the present day. In the 1940s the company was nationalised and from 1961 run by a cooperative. During 1990s, widespread unemployment, labour precariousness and interrupted production led the factory administrators to declare bankruptcy due to a substantial debt. However, in 1998 the workers occupied the factory, managed to re-negotiate the debt and started to work again, despite receiving little or no salary, through a self-managed cooperative. 


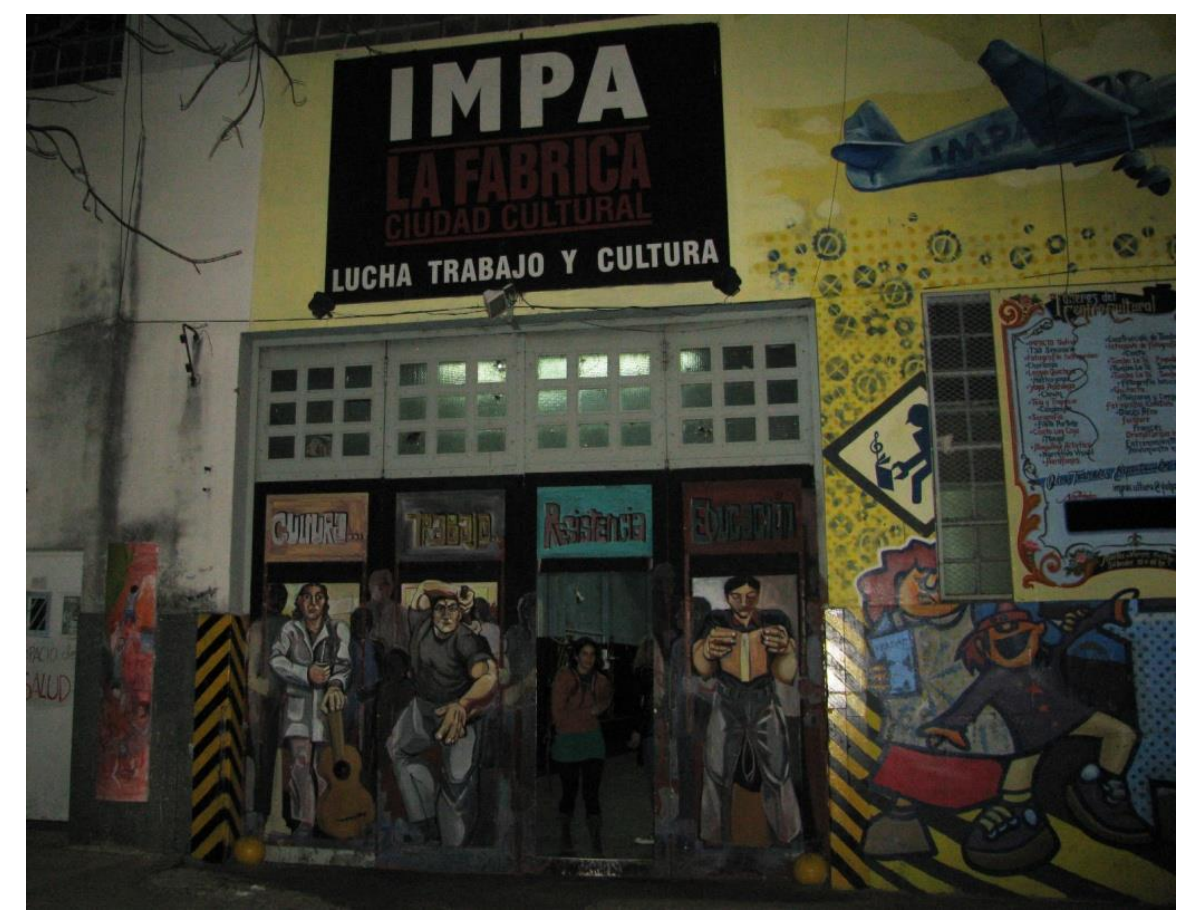

Fig. 3. IMPA's facade. Source: Dinardi, 2014.

Apart from producing aluminium packaging, a year later the factory started to produce cultural activities. An open cultural centre was created, IMPA Ciudad Cultural, and began to offer community workshops across different areas, ranging from popular music, theatre, puppetry and dance, to circus, capoeira, mask-making, tango and many more. There is also a theatre, a radio and a TV channel, a free health centre, a popular education college, an adults' school and a museum. In 2001 it was declared 'site of cultural interest' by the municipal government, which described it as the city's most creative and valuable experience, born out of the recent crisis (GCBA, 2001).
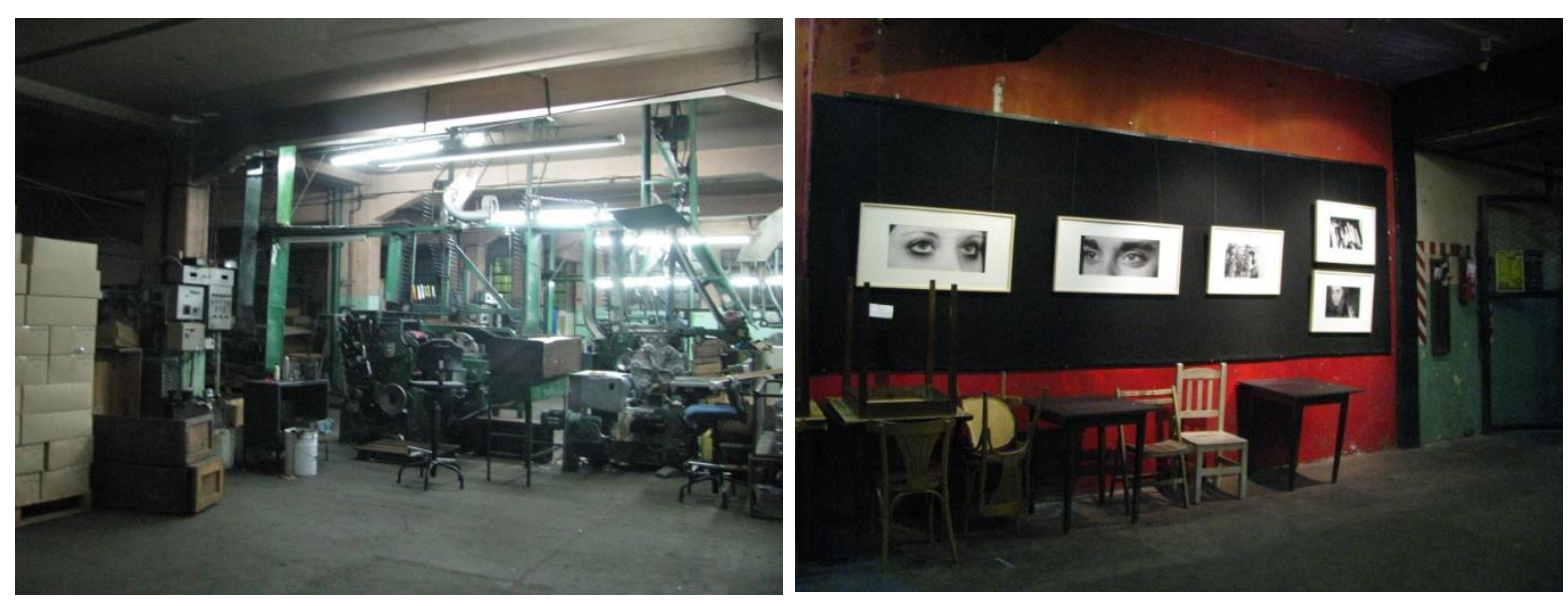
Fig. 4. IMPA's aluminium production and cultural space. Source: Dinardi, 2014.

Despite working at times with no light or electricity as a result of service-cuts, the factory cultural centre 'has managed to offer productions and expressions of great artistic quality, demonstrating that it is possible to produce valuable cultural facts without large budgets or logics ruled by commercial success' (Bokser, 2010:7). It runs on collaboration, voluntary work, financial contributions from workers, and the selfmanagement of technical equipment. A total of 180 people work at the factory, including 49 industrial workers, 50 cultural centre staff (teaching and administrative), 42 college teachers, 22 community radio and TV staff, and other co-op workers (TELAM, 2015). Bokser (2010) argues that it is precisely in the problems cultural and industrial workers face on a daily basis that bonds are strengthened among them and between them and the building. This, he notes, leads to the erasure of hierarchical distinctions between audiences, workers and artists, as each of them share the common experience of being in a factory with very limited resources. In fact, 'notions of solidarity, mutuality, and voluntary altruism constitute prime rationales of non-profit activity' (Toepler, 2003:237).

After a few years of being occupied, IMPA became the target of legal disputes with the creditors. In 2005 the cultural centre and college closed down and in 2008 workers were evicted from the premises and protests were violently repressed by the police. Finally, after camping and resisting the eviction, the workers managed to occupy the factory and re-opened the facilities. In 2015 the Senate passed a new law in favour of the workers and at present the IMPA co-operative awaits the definitive expropriation of the factory.

The factory workers' success in self-management led to the emergence of what has been termed the IMPA's method, 'occupy, resist and produce', which has inspired other social organisations' political struggles, cooperative efforts and squatting methods. 
Today many of the recovered factories in Argentina are experiencing harsh economic times due to the existing recession, the high increase in public utilities and the ongoing legal cases involving workers' eviction orders alongside a lack of official support to forms of self-managed industrial production.

\section{Conclusion}

This chapter has examined how derelict industrial infrastructures have been appropriated from the bottom-up and re-signified through cultural and artistic practices, leading to the emergence of 'grassroots creative hubs'. This final section reflects on the relations that make up the everyday functioning of the hubs and provide some concluding remarks about their future prospects.

The birth of grassroots creative hubs has been shown to be unplanned and spontaneous. We have seen that the occupation of Bhering factory was initiated by one individual visual artist who then invited her friends to join; IMPA, in contrast, was taken over by a group of factory labourers who used to work in the premises and wanted to preserve their jobs in a context of tough economic crisis.

In terms of cultural content, we have seen that IMPA offers a diverse range of activities that could be grouped under the category of 'popular culture', and Bhering concentrates on the arts and the creative industries. While in IMPA a wide diversity of non-commercial cultural and arts activities unusually co-exist in a factory setting with metallurgic workers, in Bhering artists pay rent to use the factory as workspace. IMPA attracts a mix of audiences that bring together adult students, party goers, artists, militants, local residents, and members of other workers' movements and social organisations. Both Bhering and IMPA have established links with external organisations; being part of formal cultural circuits in the city helps the factories widen and diversify their audiences. 
The recovered factories operate under different management and funding models. In the case of IMPA, funding is still an area of concern as workers rely on individual donations and run the cultural centre with whatever resources they manage to find. They applied for public funding without success, for not meeting the city government's safety and licensing requirements for cultural venues (Bokser, 2010). Bhering artists, on the other hand, have been awarded municipal funding for a one-off initiative aimed at strengthening the relationship with local residents.

While Bhering artists have struggled to create a civil association during times of eviction threats, in IMPA cultural resistance and political contestation shape the cultural programme on offer. The potential of cultural activities to imagine more just societies through collaborative practices has been invoked by IMPA's cultural workers. In this sense, a decentralised and horizontal management of cultural activities as well an ad-hoc planning and informal decision-making at IMPA allowed for cultural development based on experimentation and the creation of alternative spaces of socialisation, which widen social inclusion networks (De Felice, 2007).

Considering the future prospects of creative hubs, there are different scenarios in each case. Because IMPA has pioneered the recovered factories movement in Argentina, it has accumulated several years of experience in conflict management, receiving support from other social movements and political organisations. Yet the definitive transfer of property ownership to the workers is still the object of legal processes and political struggles. Bhering, in contrast, is a fairly recent initiative and its early development reminds of traditional processes of artists-led urban regeneration contributing to gentrification, exemplified internationally in the familiar cycle of artist zones in London, Berlin, Toronto and New York (Evans and Shaw, 2004:17). Extreme caution might prevent Bhering artists from becoming part of gentrification-led interventions in a much-disputed area of Rio de Janeiro. 
When researching creative hubs, how can we as social scientists shed light on a phenomenon that is increasingly becoming globalised, yet in the process not promote it as the organizing mode par excellence of those working in the creative economy? McRobbie points to the need to generate greater debate about questions of method and radical reflection about the conduct of research in the field of creative labour studies, developing 'a new kind of post-industrial sociology with the university as hub' and with cross-sector knowledge-sharing and partnerships with creative workers (McRobbie, 2016:936). Perhaps an alternative way forward to assess creative hubs is the extent to which artists and other creative workers effectively and creatively engage with the local population, be that through collaboration or training opportunities, contributing to revitalise - rather than gentrify - the areas surrounding such hubs.

We have seen that urban creativity is an open-ended process with an uncertain future. Several factors currently threaten the development of grassroots creative hubs, namely, lack of resources, unpaid voluntary work, eviction threats, safety issues, limited technical infrastructure and increasing commercialisation. This signals an area where cultural policy action could be needed by providing financial and legal support as well as a platform for experimentation in participatory policy design, going beyond a rhetorical call for participation to actually provide artists greater voice and influence over the decisions that affect their lives (Jenkins, 2014:271) and work, and in so doing, contribute to the sustainability of creative hubs.

\section{Acknowledgements}

The author would like to thank the Urban Studies Foundation for funding the research upon which this paper is based during a postdoctoral fellowship (2013-2016) at City University London. 


\section{References}

Bokser, J. (2010) 'Tensiones de la autogestión cultural: el Centro Cultural de IMPA', conference paper presented at the II Jornadas Internacionales de Problemas Latinoamericanos, Universidad Nacional de Córdoba, 19-20 November 2010. Available online at: http://fisyp.org.ar/media/uploads/autogestion.pdf\#page $=5$ [Accessed 20 May 2016]

Buitrago F. and Duque, I. (2013) La economía naranja: Una oportunidad infinita. New York: Banco Interamericano de Desarrollo.

Carlos, C. A. S. L. (2010) Um Olhar Crítico sobre a Zona Portuária da Cidade do Rio de Janeiro, Bitacora 17 (2), pp. 23-54.

Cresswell, J. (ed.) (2010) 'Hub', Oxford Dictionary of Word Origins, New York: Oxford University Press, p. 215.

De Felice, A. (2007) 'La fábrica cultural, otra forma de producción simbólica', Reflexión Académica en Diseño y Comunicación, 8 (8), pp. 85-94.

Dinardi, C. (2015) Unsettling the role of culture as panacea: The politics of culture-led urban regeneration in Buenos Aires, City, Culture \& Society, 6 (2), pp. 9-18.

Diniz, N. (2014) Porto Maravilha: antecedentes e perspectivas da revitalização da região portuária do Rio de Janeiro, Rio de Janeiro: Editora Letra Capital.

Evans, G. (2009), "Creative Cities, Creative Spaces and Urban Policy", Urban Studies, 46 (5/6), pp. 1003-1040. 
Evans, G. and Shaw, P. (2004) The Contribution of Culture to Regeneration in The UK: A Report to the DCMS, London: London Met.

Fessler Vaz, L. and Silveira, C. B. (1994) A Área Central do Rio de Janeiro, Cadernos IPPUR/UFRJ, Aeo VIII, N²/3, pp. 95-105.

Gobierno de la Ciudad de Buenos Aires, GCBA (2001) 'Sitios de Interés Cultural', available online:

http://www.buenosaires.gob.ar/areas/cultura/cpphc/sitios/?menu id = 14928 [Accessed 15 May 2014]

Jaguaribe, B. (2011) Imaginando a "cidade maravilhosa": modernidade, espetáculo e espaços urbanos, Revista FAMECOS, 18 (2), pp.327-347.

Jenkins, H. (2014) 'Rethinking 'Rethinking Convergence/Culture"', Cultural Studies, 28 (2), pp. 267-297.

McRobbie, A. (2016), Towards a Sociology of Fashion Micro-Enterprises: Methods for Creative Economy Research, Sociology, 50 (5), pp. 934-948.

Mehrotra, R., Vera, F. and Mayoral, J. (2016) 'Ephemeral urbanism: Cities in Constant Flux', Venice Biennale exhibition. Video presentation available online at: https://www.youtube.com/watch?v=vzEcVEFdIHs [Accessed 12 September 2017].

Micheletto, K. (2003) 'Rescate a puro candombe', Pagina 12, 20/12/2003, available online: http://www.pagina12.com.ar/diario/espectaculos/6-29498-2003-12-20.html [Accessed 15 May 2014]. 
Molotch, H. (1976) 'The City as a Growth Machine: Toward a Political Economy of Place', American Journal of Sociology, 82 (2), pp. 309-332.

Mommaas, H. (2004) Cultural Clusters and the Post-Industrial City: Towards the Remapping of Urban Cultural Policy, Urban Studies, 41(3), pp. 507-532.

Montgomery, J. (1995) The Story of Temple Bar: Creating Dublin's cultural quarter, Planning Practice \& Research, 10 (2), pp. 135-172.

O'Connor, J, and Gu, X. (2014) Creative industry clusters in Shanghai: a success story?,International Journal of Cultural Policy, 20 (1), pp. 1-20.

Pratt, A. C. (2009) Urban Regeneration: From the Arts 'Feel Good' Factor to the Cultural Economy: A Case Study of Hoxton, London, Urban Studies, 46 (5-6), pp. 1041-1061.

Rivas Molina, F. (2016) 'Miles de obreros tomaron sus fábricas en 2001, la mayoría aún resiste', Diario El País, 16/12/16. Available online: https://elpais.com/internacional/2016/12/14/argentina/1481679343 026699.html [Accessed online 12th September 2017].

Rossi, U. \& Di Bella, A. (2017), Start-up urbanism: New York, Rio de Janeiro and the global urbanization of technology-based economies, Environment and Planning A, 49 (5), pp. 999-1018.

Scott, A. (2006) Creative cities: conceptual issues and policy questions, Journal of Urban Affairs, 28(1), pp. 1-17.

Strauss, W. (2010), "How to build a creative hub", Broadcast, p. 24. 
TELAM (2015) 'Exproprian el IMPA y la ceden a la cooperativa que la maneja desde 1998', 04/12/2015, Telam, available online: http://www.telam.com.ar/notas/201512/129083-expropiacion-impa-cooperativa.php $\begin{array}{llll}\text { [Accessed } & \text { 12th } & \text { September }\end{array}$

Toepler, S. (2003) 'Grassroots Associations Versus Larger Nonprofits: New Evidence from a Community Case Study in Arts and Culture', Nonprofit and Voluntary Sector Quarterly, 32 (2), pp. 236-251.

Zukin, S. (1989) Loft living: culture and capital in urban change, New Brunswick, N.J.: Rutgers University Press.

Zukin, S. and Braslow, L. (2011) The life cycle of New York's creative districts: Reflections on the unanticipated consequences of unplanned cultural zones, City, Culture and Society, 2 (3), pp. 131-140. 